\title{
Haematological Characteristics of African Catfish (Clarias gariepinus) Fed Dietary Inclusion Levels of Green Leaf (Amaranthus cruentus)
}

\author{
${ }^{1}$ Ariweriokuma S.V, ${ }^{2}$ Gabriel U.U, ${ }^{3}$ Deekae S.N, ${ }^{*}{ }^{4}$ Akinrotimi O.A \\ ${ }^{1,2,3}$ Department of Fisheries and Aquatic Environment, Rivers State University of Science and \\ Technology, PMB 5080 Port Harcourt, Nigeria. \\ ${ }^{4}$ African Regional Aquaculture Center of Nigeria Institute for Oceanography and Marine Research \\ Buguma, P.M.B 5122 Port Harcourt, Rivers State, Nigeria. \\ "ojoakinrotimi@yahoo.com
}

\begin{abstract}
This study determined the haematological responses of the African catfish (Clarias gariepinus) fed graded levels of green leaf (Amaranthus cruentus) of the Amaranthecea family. 360 fingerlings of Clarias gariepinus fish of mean weight $1.98 \pm 0.25 \mathrm{~g}$ from the same stock were randomly stocked at 20 fish per plastic aquarium at 6 treatment levels designated $C_{0}$ (control ), $X_{20}, X_{40}, X_{60}, X_{80}$ and $X_{100}$, each with 3 replicates representing the dietary levels. The experiment was carried out for 16 weeks. The result obtained indicated that the haematological variables, the packed cell volume (PCV), Red blood cells (RBC) and leucocrit values in all the treatment groups were within the same range with the control values. While the haemoglobin $(\mathrm{Hb}), \mathrm{Red}$ Blood indices (MCHC, MCH, MCV) and the platelets in all the dietary levels were within the normal range values. The total White Blood Cell (WBC) counts were low in all the levels when compared to the control. The leaf is therefore an economically viable alternative to commercial fish premix in the diet of $C$. gariepinus when used as a premix at the $100 \%$ inclusion level. It supported the growth and survival of the fish and was able to provide a good health status for the fish.
\end{abstract}

Keywords: Haematology, Green leaf, Fish feed, Aquaculture, Vitamins.

\section{INTRODUCTION}

In recent times the growing global demand for fish cannot be met by supplies from captured fisheries, hence the need for reliable and viable system of increasing fish production to meet the high demand for fish consumption and the aquaculture industry seems to provide the answer (Gabriel et al., 2007a; Akinrotimi et al., 2011a; FAO,2014). Aquaculture is the application of physical and biological principles to business of rearing fish and other aquatic organisms in an artificial enclosure containing water (Ajayi, 1999; Adeogun et al., 2010). It entails farming of aquatic organisms and plants in fresh, brackish or marine water. Unlike capture fisheries, aquaculture requires deliberate human intervention in the organisms 'productivity which results in yields that exceed those from the natural environment alone (Ozigbo et al., 2014). In many parts of the globe the aquaculture activities has increased giving rise to global efforts to eliminate hunger and malnutrition by supplying fish and other aquatic products rich in protein, essential fatty acids and minerals (FAO, 2012; Akinrotimi et al., 2015).

In Nigeria, like other parts of the world, the catfish (C. gariepinus) have gained much prominence as important species for aquaculture, with high commercial value and acceptance among consumers (Yisa and Olufeagba, 2005; Akinrotimi et al., 2014a). They are grown by a large number of farmers in many countries, with a total production of over 300,000 tones, which was valued at US $\$ 410$ million in 2006 (FAO, 2004; Ekunwe and Emokaro, 2009). Currently, cultured C. gariepinus contributes nearly $60 \%$ to the total global aquaculture production (George et al., 2013), while it contributes nearly 90\% of the total fish production in Nigeria, through intensive culture (AIFP, 2004; Adewumi and Olaleye, 2011; Akinrotimi et al., 2014b).

The catfish farmers in Nigeria are currently faced with the problem of inadequate supply and prohibitive cost of quality fish feeds (Omitoyin, 2006; Gabriel et al., 2007b). Akinrotimi et al. (2007a) reported that in aqua feed production the contributions of vitamins from ingredients are very crucial. This is because vitamins from ingredient sources make a significant contribution to 
observable fish performance. However, the vitamin levels are reduced during processing methods, especially pelleting and extrusions. These have been described as aggressive processing methods which have been documented to cause significant destruction of vitamins in fish diets and have a variety of effects on feed quality. Commercially packaged premix is usually added to the ingredients to augment the vitamin loss due to processing (Akinrotimi et al., 2011b). Sometimes the vitamin premix may not be available for feed formulation especially for fish farmers in the rural areas, at times, the potency of commercial premix may be reduced due to long storage. There is therefore the need to search for a more available, accessible and reliable plant based materials that could be used as replacement for commercial premix.

Haematology has been developed and well utilized in assessing the health of man and livestock. Akinrotimi et al. (2007b) opined that fish haematology would be useful in the assessment of suitability of feeds or feed mixtures, evaluation of fish conditions, determination of toxic effect of substances as well as diagnosis of disease. Developing reference intervals or normal range values are also a necessary first step in determining which specific haematological changes can be associated with disease conditions (Hrubec and Smith, 2004; Akinrotimi et al., 2007c; Gabriel et al., 2007c;Akinrotimi et al., 2011b). This work therefore provides information on the suitability of replacing commercial premix partially and totally with Amaranthus cruentus green leaf serving as a premix for optimal performance of fish and for profit maximization in the aquaculture industry.

\section{MATERIALS AND MethodS}

\subsection{Project Location}

This work was carried out at the Department of Fisheries and Aquatic Environment laboratory at the Rivers Sate University of Science and Technology, Nkpolu- Oroworukwo, Port Harcourt, Rivers State, Nigeria.

\subsection{Source of Experimental Fish and Acclimation of Fish}

Three hundred and sixty (360) fingerlings of Clarias gariepinus fish of the same stock and mean weight $1.98 \pm 0.25 \mathrm{~g}$ were purchased from the African Regional Aquaculture Centre (ARAC), Aluu, Port Harcourt. They were transported in oxygen bags to the experimental site. The fish was acclimated to laboratory conditions for two weeks and were fed twice daily with the locally purchased feed at $5 \%$ bodyweight.

\subsection{Experimental Design, Rearing Units and Stocking of Fish}

The design of the experiment is a Completely Randomized Design (CRD) with six treatment levels at three replicates each, based on the levels of replacement of commercial premix. A total of 18 transparent plastic container of dimension $(1.2 \mathrm{~m} \times 0.6 \mathrm{~m} \times 0.4 \mathrm{~m})$ each, were used for the experiments. The 18 basins were labeled based on treatment levels and replicates. Each basin was stocked with twenty (20) fingerlings. The initial total and mean weights ( $\mathrm{g}$ ) were taken using sensitive weighing balance before the start of the experiment. A total of 360 (three hundred and sixty) fingerlings were stocked.

\subsection{Formulation and Preparation of Experimental Diets}

The feed ingredients used in this study were purchased from local market, these include: fish meal, soya bean meal, groundnut cake, corn meal, red palm oil, iodized salt, commercial purchased fish premix and dried and ground Amaranthus cruentus green leaf which served as the test premix that replaced the fish premix partially and totally. All the feed ingredients were measured out according to feed formulation suitable for Clarias gariepinus fish (Table 1).

Premixes are normally added to feeds at a rate of 0.5 to 1 percent per $100 \mathrm{~g}$ with an extra 0.5 percent to make up for vitamin losses during processing (Barrow et al., 2008). The green leaf was dried for about one and half weeks and was grinded with a blender into very fine particles. All the feed ingredients measured out summed up to a hundred grams (Table 1). The premixes were the only variables in weight of the feed ingredients; $1 \mathrm{~kg}$ of the feed ingredients was measured out base on the $100 \mathrm{~g}$ in each feed formulation. The measured out ingredients of $1 \mathrm{~kg}$ were mixed together and hot water at the rate of $30 \mathrm{ml}$ per $\mathrm{kg}$ was added to the mixed feed. Some paste of garri (cassava starch) as binder at the rate of $30 \mathrm{~g}$ per $\mathrm{kg}$ was added. A pinch of salt $(0.5 \mathrm{~g}$ per $\mathrm{kg})$ and palm oil $(3 \mathrm{ml}$ per $\mathrm{kg})$ were also added for taste and palatability. Other nutrients that might be limiting (i.e not found in 
sufficient quantity in the fish feed), such as vitamin $\mathrm{C}$, methionine and lysine amino-acids and bone meal casa source of mineral salts) were also added (Table 1).

The thoroughly mixed $1 \mathrm{~kg}$ feed ingredients was then shared into six portions designated $\mathrm{C}_{\mathrm{O}}$ (control), $\mathrm{X}_{20}, \mathrm{X}_{40}, \mathrm{X}_{60}, \mathrm{X}_{80}$ and $\mathrm{X}_{100}$. The control diet contained $100 \%$ commercial fish premix, while $\mathrm{X}_{100 \text { diet }}$ contained $100 \%$ green leaf powder only. $\mathrm{X}_{20}$ portion contained $80 \%$ fish premix and $20 \%$ green leaf powder while $\mathrm{X}_{40}$ portion contained $60 \%$ fish premix and $40 \%$ green leaf powder $\mathrm{X}_{60}$ portion contained $40 \%$ fish premix and $60 \%$ green leaf powder, while $\mathrm{X}_{80}$ portion contained $20 \%$ fish premix and $80 \%$ green leaf. Six practical diets were therefore formed with partial and total replacement of the commercial fish premix with green leaf powder. The dough of each practical diet was then extruded separately through a meat mincer to produce strand which were cut into pellets and sun dried separately for 72 hours or more. The dry pellets were broken into crumbles that can be swallowed by the finger lings and were separated with Labels in small plastic bags. These were stored on wooden racks in a cool dry room.

\subsection{Feeding of Experimental Fish}

The fingerlings were handfed to visual satiety twice daily at $8.00 \mathrm{hr}$ and $17.00 \mathrm{hrs}$. The daily ration of $5 \%$ body weight was divided into two and half fed to fish each time. The weight of feed fed was adjusted every two weeks. The fish were cultured for 16 (sixteen) weeks.

\subsection{Estimation of Water Quality Parameters}

Water in all experimental basins was changed every two days, throughout the trial period. The water quality variables were monitored fortnightly. The temperature of the water was taken with mercury in glass. Alkalinity, water hardness and dissolved oxygen were determined by the method APHA, (1998). The water $\mathrm{pH}$ was measured in situ in each of the basins with a $\mathrm{pH}$ meter (Hanna products Portugal). Nitrite and Ammonia were determined by using Fish Farmers Water Quality Test Kit; model FF - 1A, Cat. No. $2430-02$

\subsection{Evaluation of Haematological Parameters}

\subsubsection{Blood Collection}

Blood samples for haematological analysis were collected and preserved in sterile ethylene diamine tetra - acetic acid (EDTA bottles, 480 in number) used for the blood collection and labeled for easy identification according to each experimental treatments. EDTA salt was used for the haematological analysis as the anticoagulants since it gives the best results with preserved blood (Blaxhall and Daisley, 1973, Akinrotimi et al., 2007d; Gabriel et al., 2011a). The blood was drawn from caudal vein (Vena cava) located close to the vertebrae column in the caudal part of the fish (Akinrotimi et al., 2010). Fish were caught individually with a hand net. Blood samples were obtained with $5 \mathrm{ml}$ disposable syringes and 21-gauge hypodemic needle. The collected blood sample 1blood was transferred into EDTA bottles for analysis.

\subsubsection{Erythrocyte Sedimentation Rate (ESR)}

The Westergren ESR tube was used to draw one part of 3.8 percent sodium citrate to four (4) part of blood. The blood was taken from an anticoagulated blood containing EDTA. The blood as well mixed in the tube and this was drawn to the zero mark. The tube was then stood on the Wintrobe stand vertically for one hour after which the level of the red cells was read as the ESR (Albritton, 1992).

\subsubsection{Leucocytes}

Blood was drawn to $0.5 \mathrm{~cm}$ marks and the tip of the pipette was wiped. The pipette was placed in Leucocytes diluting Fluid and filled slowly to the $11 \mathrm{~cm}$ marks above the bulb making 1.20 dilutions. The pipette was thoroughly mixed for 3 minutes, 2 or 3 drops were discarded before filling the Neubaeur counting chamber. Blood was allowed to stand for 1 minute to settle down. Cells in each of the four large corner squares of the counter were counted under low power; Illumination was reduced to detect the leucocytes as dark uniforms objects as they were counted (Blaxhall and Daisley, 1973).

\subsubsection{Differential Counts}

Differential count was done by making a thin film on a clean grease free slide with a spreader placed at an angle of $45^{\circ}$ over a drop of blood on the slide. The spreader was allowed to touch the blood 
while spreading along the edge of the spreader and this was moved along the slide to make a thin film. The thin film on the slide was allowed to dry. This was then stained with Leishmann stain for 10 minutes after which the was washed off. The film was air-dried and examined under the $\mathrm{x} 100$ magnification (oil immersion) objective (Brown, 1980).

\subsubsection{Platelets (Thrombocytes)}

The determination of platelets was done by putting diluting fluid into the bulb of an erythrocyte diluting pipette, and excess fluid was expelled. Blood was drawn from EDTA embedded vial to the 0.5 marks, followed by diluting fluid to the 101 marks. Pipette content was mixed for some minutes and several drops were discarded to fill both sides of the counting chamber. Content was allowed to stand for 10 minutes for erythrocytes to settle. The light partially reduced; platelets were counted in the entire central ruled of each side of the counting chamber (Brown, 1980).

\subsubsection{Red Blood Cell Indices}

The red blood cell indices were calculated using the following formulae:

\section{Mean Corpuscular Volume (MCV)}

Values of MCV were calculated using the formula

$\mathrm{MCV}=\frac{\text { Haematocrit }(\text { Pack Cell Volume } \times 10)}{R B C(\operatorname{Re} d \text { Blood Cell })}($ Miale, 1982).

\section{Mean Corpuscular Haemoglobin (MCH)}

Values of $\mathrm{MCH}$ were calculated using the formula

$\mathrm{MCH}=\frac{\text { Haematocrit Conc }}{R B C}($ Miale, 1982).

\section{Mean Corpuscular Haemoglobin (MCHC}

Values of MCHC were calculated using the formula:

MCHC $=\frac{\text { Haemoglobi } \times 100}{\text { Haematocrit }}$ (Miale, 1982).

\subsection{Statistical Analysis}

The data obtained from the study were collated and analyzed using statistics software 8.0 for windows. Data were first tested for normality (Kolmogorov - Smirnov test) and homosesdasticity of variance (Bartetts test). When these conditions were satisfied, a two way analysis of variance (ANOVA) was employed to reveal significant differences in measured variables among control and experimental groups. When a difference was detected $(\mathrm{P}<0.05)$, Tuckey's multiple comparison test was applied to identify which treatments were significantly different (Wahua, 1999).

\section{RESUlts}

The water quality variables indicated that the $\mathrm{p}^{\mathrm{H}}$ values ranged from $6-23 \pm 0.31$ to $6.44 \pm 0.45$, while dissolved oxygen ranged from $4.29 \pm 0.42$ to $6.22 \pm 1.02 \mathrm{mg}$ Do/l. Temperature values ranged from $27.39 \pm 0.49$ to $27.73 \pm 0.43^{0} \mathrm{C}$ while Nitrite ranged from $0.44 \pm 0.11$ to $0.59 \pm 0.09 \mathrm{mg} / \mathrm{l}$. Ammonia ranged from $0.11 \pm 0.02$ to $0.15 \pm 0.06 \mathrm{mg} / \mathrm{l}$ while total hardness ranged from $44.64 \pm 2.00$ to $47.21 \pm$ 3.13 (Table 2).

The range value of $\mathrm{Hb}$ in the experimental fish was from $(6.53 \pm 1.57)$ to $(9.13 \pm 0.81)$. The highest value $(9.13 \pm 0.81)$ was recorded in the control diet Co, followed by $\mathrm{X}_{80}(8.77 \pm 1.08)$ and $\mathrm{X}_{100}$ diet $(8.37 \pm 1.53)$ (Table 3) There were no significant differences $(\mathrm{P}>0.05)$ in the treatment group.The highest PCV value $(27.00 \pm 1.75)$ in the experimental fish was recorded in the control while the lowest value $(21.00 \pm 3.61)$ was recorded in $\mathrm{X}_{40}$ diet. There were no significant differences $(\mathrm{P}>0.05)$ between the control and the other treatment groups. The range of values in leucocrit was from (1.67 \pm $0.58)$ to $(2.67 \pm 0.58)$. The lowest value $(1.67 \pm 0.58)$ was recorded in $X_{80}$ diet and the highest value $(2.67 \pm 0.58)$ in $\mathrm{X}_{40}$ diet. There were no significant differences $(\mathrm{P}>0.05)$ between the treatment group. The results of the WBC showed the highest value $(7.53 \pm 1.25)$ in the control followed by $\mathrm{X}_{20}$ diet 
$(4.20 \pm 0.00)$. The lowest value $(2.55 \pm 0.00)$ was recorded in diets $X_{80}$ and $X_{100}$ diets. The control value was significantly different $(\mathrm{P}<0.05)$ from the other dietary levels. (Table 3$)$. The highest platelet value $(250.00 \pm 0.00)$ was recorded in the control diet Co followed by $\mathrm{X}_{40}$ diet. The lowest value (166.67 \pm 76.36$)$ was recorded on the $\mathrm{X}_{60}$ diet. There were no significant differences (P0.05) between the control and diets $\mathrm{X}_{20}, \mathrm{X}_{40}$ and $\mathrm{X}_{100}$.

There was no significant difference $(\mathrm{P}>0.05)$ in the mean values of $\mathrm{RBC}$ in the treatment groups during the trial period. The range of values was from $(2.23 \pm 0.12)$ in $\mathrm{X}_{40}$ to $(2.90 \pm 0.35)$ in the control diet. There was no significant difference $(\mathrm{P}>0.05)$ in all the treatment groups. The results of MCHC indicated no significant difference $(\mathrm{P}>0.05)$ between the dietary treatment groups whose range was from $(31.67 \pm 0.58)$ in $\mathrm{X}_{100}$ diet to $(33.00 \pm 0.00)$ in the control diet. There was no significant differences $(\mathrm{P}>0.05)$ in all the treatment groups. The values ranged from $(31.66 \pm 0.58)$ in $\mathrm{X}_{60}$ to $(33.00 \pm 0.00)$ in the control. There were no significant differences $(\mathrm{P}>0.05)$ in all the treatment groups. There were no significant differences $(\mathrm{P}>0.05)$ in the result for MCV in the treatment groups, the range of value is from $95.00 \pm 0.00$ to $96.33 \pm 0.58$.

The highest value $(34.00 \pm 0.00)$ was recorded in diet $\mathrm{X}_{40}$ while the lowest values $(22.38 \pm 0.58 ; 30.67$ $\pm 5.03)$ were recorded in diets $X_{100}$ and diets $X_{80}$ respectively. There were significant differences $(\mathrm{P}>0.05)$ in values in some of the treatment groups. The highest value $(77.33 \pm 2.52)$ was recorded in diet $\mathrm{X}_{80}$ followed by diet $\mathrm{X}_{100}(75.00 \pm 4.36)$. There were no significant differences $(\mathrm{P}>0.05)$ between the control and diets $X_{20}, X_{40}$ and $X_{60}, X_{80}$ diet and $X_{100}$ diets have similar values (77.33 \pm 2.52$)$ and (75.00 \pm 4.36$)$ respectively. The range of values was from $(66.00 \pm 0.00)$ to $(77.33 \pm 2.52) X_{40}$ recording the lowest value $(66.00 \pm 0.00)$. There were some significant difference $(\mathrm{P}>0.05)$ among some of the groups (Table 3).

Table1. Percentage Composition of Experimental Diets

\begin{tabular}{|l|l|l|l|l|l|l|}
\hline \multicolumn{9}{|c|}{ Experimental diets } \\
\hline Ingredients & $\mathrm{C}_{0}$ (control), & $\mathrm{X}_{20}$ & $\mathrm{X}_{40}$ & $\mathrm{X}_{60}$ & $\mathrm{X}_{8}$ & $\mathrm{X}_{100}$ \\
\hline Commercial premix & 1.00 & 0.80 & 0.60 & 0.40 & 0.20 & - \\
\hline Amaranthus premix & - & 0.20 & 0.40 & 0.60 & 0.80 & 1.00 \\
\hline Fish meal & 27.75 & 27.75 & 27.75 & 27.75 & 27.75 & 27.75 \\
\hline Corn meal & 12.45 & 12.45 & 12.45 & 12.45 & 12.45 & 12.45 \\
\hline Soya been meal & 36.80 & 36.80 & 36.80 & 36.80 & 36.80 & 36.80 \\
\hline Groundnut cake & 15.50 & 15.50 & 15.50 & 15.50 & 15.50 & 15.50 \\
\hline Palm oil & 0.30 & 0.30 & 0.30 & 0.30 & 0.30 & 0.30 \\
\hline Vitamin C & 0.30 & 0.30 & 0.30 & 0.30 & 0.30 & 0.30 \\
\hline Methione & 0.30 & 0.30 & 0.30 & 0.30 & 0.30 & 0.30 \\
\hline Lysine & 0.30 & 0.30 & 0.30 & 0.30 & 0.30 & 0.30 \\
\hline Common salt & 0.20 & 0.20 & 0.20 & 0.20 & 0.20 & 0.20 \\
\hline Bone meal & 2.00 & 2.00 & 2.00 & 2.00 & 2.00 & 2.00 \\
\hline Garri (binder) & 3.00 & 3.00 & 3.00 & 3.00 & 3.00 & 3.00 \\
\hline Total & 100 & 100 & 100 & 100 & 100 & 100 \\
\hline $\begin{array}{l}\text { Energy } \\
\text { Kcal/Kg/ME }\end{array}$ & 3780.40 & 3780.40 & 3780.40 & 3780.40 & 3780.40 & 3780.40 \\
\hline
\end{tabular}

Each $2.5 \mathrm{~kg}$ content of fish commercial premix contains

Vitamin A-8,000 iu

Vitamine E -6,000 iu

Thiamine $-B_{1}-1,500 \mathrm{mg}$

Pyridxine $-B-1,500 \mathrm{mg}$

Vital $B_{12}-10 m g$

Folic acid - $50 \mathrm{mg}$

Choline chloride -2000mg

Riboflavin $4000 \mathrm{mg}$

Niacin 10000mg

Panthotenic acid -5000mg

Biotin 20mg

\author{
Manganese - $80 \mathrm{mg}$ \\ Iron-20mg \\ Iodine $-1.2 \mathrm{mg}$ \\ Cobalt-200mg \\ Vit $D_{3}-1600 \mathrm{iu}$ \\ Vit $K-2000 m g$
}

Zinc 500mg

Copper -50mg

Selenium-200mg

Anti oxidant- $125 \mathrm{~g}$ 
Ariweriokuma S.V et al.

Table2. Mean values of physicochemical parameters of water in the experiment containers.

\begin{tabular}{|l|l|l|l|l|l|l|}
\hline \multicolumn{7}{|c|}{ Experimental diets } \\
\hline Parameters & $\mathrm{C}_{0}$ (control), & $\mathrm{X}_{20}$ & $\mathrm{X}_{40}$ & $\mathrm{X}_{60}$ & $\mathrm{X}_{8}$ & $\mathrm{X}_{100}$ \\
\hline PH & $6.44 \pm 0.45^{\mathrm{a}}$ & $6.37 \pm 0.31^{\mathrm{a}}$ & $6.23 \pm 0.31^{\mathrm{a}}$ & $6.28 \pm 0.17^{\mathrm{a}}$ & $6.33 \pm 0.36^{\mathrm{a}}$ & $6.43 \pm 0.35^{\mathrm{a}}$ \\
\hline $\begin{array}{l}\text { Dissolved } \\
\text { Oxygen }(\mathrm{mg} / \mathrm{L})\end{array}$ & $6.22 \pm 1.02^{\mathrm{a}}$ & $5.71 \pm 0.42^{\mathrm{a}}$ & $4.29 \pm 0.42^{\mathrm{a}}$ & $4.64 \pm 0.70^{\mathrm{a}}$ & $5.71 \pm 1.23^{\mathrm{a}}$ & $5.83 \pm 1.09^{\mathrm{a}}$ \\
\hline Temperature $\left(\mathrm{O}_{\mathrm{c}}\right)$ & $27.39 \pm 0.49^{\mathrm{a}}$ & $27.41 \pm 0.43^{\mathrm{a}}$ & $27.57 \pm 0.23^{\mathrm{a}}$ & $27.47 \pm 0.42^{\mathrm{a}}$ & $27.47 \pm 0.42^{\mathrm{a}}$ & $27.40 \pm 0.42^{\mathrm{a}}$ \\
\hline Nitrite $(\mathrm{mg} / \mathrm{l})$ & $0.44 \pm 0.11^{\mathrm{a}}$ & $0.48 \pm 0.09^{\mathrm{a}}$ & $0.58 \pm 0.09^{\mathrm{a}}$ & $0.55 \pm 0.10^{\mathrm{a}}$ & $0.49 \pm 0.10^{\mathrm{a}}$ & $0.47 \pm 0.14^{\mathrm{a}}$ \\
\hline \begin{tabular}{l} 
Ammonia $(\mathrm{mg} / \mathrm{l})$ \\
\hline $\begin{array}{l}\text { Total hardness } \\
(\mathrm{mg} / \mathrm{l})\end{array}$
\end{tabular} & $0.11 \pm 0.02^{\mathrm{a}}$ & $0.11 \pm 0.03^{\mathrm{a}}$ & $0.15 \pm 0.03^{\mathrm{a}}$ & $0.14 \pm 0.04^{\mathrm{a}}$ & $0.12 \pm 0.03^{\mathrm{a}}$ & $0.11 \pm 0.02^{\mathrm{a}}$ \\
\hline
\end{tabular}

Means with the same superscript in the column are not significantly different $(P<0.05)$.

Table3. Mean values of Haemeatological Parameters of C. gariepinus Fingerlings Fed Experimental Diets for 16 Weeks

\begin{tabular}{|c|c|c|c|c|c|c|c|c|c|c|c|}
\hline \multicolumn{6}{|c|}{ Diets } & \multicolumn{6}{|c|}{ Haematological parameters } \\
\hline & PCV & $\mathrm{Hb}$ & Leuco & Total & Platelet & RBCX & MCHC & $\mathrm{MCH}$ & $\mathrm{MCV}$ & $\mathrm{N}$ & $\mathrm{L}$ \\
\hline & $(\%)$ & $(\mathrm{g} / \mathrm{dl})$ & crite & WBC & $\mathrm{X}^{1012 \mathrm{~L}}$ & $1012 / \mathrm{L}$ & $(\%)$ & (pg) & (fl) & $(\%)$ & $(\%)$ \\
\hline Control & 27.00 & 9.13 & 2.33 & 7.53 & 250.00 & 2.90 & 33.00 & 33.00 & 95.33 & 33.00 & 67.00 \\
\hline$\left(\mathrm{C}_{0}\right)$ & \pm & \pm & \pm & \pm & \pm & \pm & \pm & \pm & \pm & \pm & \pm \\
\hline & $1.75^{\mathrm{a}}$ & $0.81^{\mathrm{a}}$ & $0.56^{\mathrm{a}}$ & $1.25^{\mathrm{a}}$ & $0.00^{\mathrm{a}}$ & $0.35^{\mathrm{a}}$ & $0.00^{\mathrm{a}}$ & $0.58^{\mathrm{a}}$ & 2.08 & $6.08^{\mathrm{ab}}$ & $6.08^{\mathrm{a}}$ \\
\hline $\mathrm{X}_{20}$ & 25.57 & 7.87 & 2.33 & 4.20 & 225.00 & 2.43 & 32.33 & 31.67 & 95.67 & 32.00 & 68.67 \\
\hline & \pm & \pm & \pm & \pm & \pm & \pm & \pm & \pm & \pm & \pm & \pm \\
\hline & $2.08^{\mathrm{a}}$ & $1.69^{\mathrm{a}}$ & $0.58^{\mathrm{a}}$ & $0.00^{b}$ & $\pm 25.00^{\mathrm{a}}$ & $0.12^{\mathrm{a}}$ & $0.58^{\mathrm{a}}$ & $0.58^{\mathrm{a}}$ & $0.58^{\mathrm{a}}$ & $6.08^{\mathrm{ab}}$ & $11.85^{\mathrm{a}}$ \\
\hline$X_{40}$ & 21.00 & 6.53 & 2.67 & 2.93 & 2.33 .33 & 2.23 & 32.33 & 31.37 & 95.00 & 34.00 & 66.00 \\
\hline & \pm & \pm & \pm & \pm & \pm & \pm & \pm & \pm & \pm & \pm & \pm \\
\hline & $3.61^{\mathrm{a}}$ & $1.57^{\mathrm{a}}$ & $0.58^{\mathrm{a}}$ & $0.75^{\mathrm{b}}$ & $76.38^{\mathrm{a}}$ & $0.12^{\mathrm{a}}$ & $0.58^{\mathrm{a}}$ & $0.58^{\mathrm{a}}$ & $1.00^{\mathrm{a}}$ & $0.00^{\mathrm{a}}$ & $0.00^{\mathrm{a}}$ \\
\hline $\mathrm{X}_{60}$ & 22.23 & 7.07 & 2.00 & 2.93 & $\mid 166.67$ & 2.43 & 32.33 & 31.66 & 95.00 & 30.67 & 77.33 \\
\hline & \pm & \pm & \pm & \pm & \pm & \pm & \pm & \pm & \pm & \pm & \pm \\
\hline & $4.51^{\mathrm{a}}$ & $0.40^{\mathrm{a}}$ & $0.00^{\mathrm{a}}$ & $\pm 0.75^{\mathrm{b}}$ & $76.38^{\mathrm{ab}}$ & 0.12 & $0.58^{\mathrm{a}}$ & $0.58^{\mathrm{a}}$ & $0.00^{\mathrm{a}}$ & $5.03^{\mathrm{a}}$ & $2.52^{\mathrm{a}}$ \\
\hline $\mathrm{X}_{100}$ & 26.07 & 8.39 & 2.00 & 2.55 & 216.67 & 2.50 & 31.67 & 31.67 & 96.00 & 22.38 & 75.00 \\
\hline & \pm & \pm & \pm & \pm & \pm & \pm & \pm & \pm & \pm & \pm & \pm \\
\hline & $1.73^{\mathrm{a}}$ & $1.53^{\mathrm{a}}$ & $0.00^{\mathrm{a}}$ & $0.00^{\mathrm{b}}$ & $28.87^{\mathrm{a}}$ & $0.52^{\mathrm{a}}$ & $0.58^{\mathrm{a}}$ & $0.58^{\mathrm{a}}$ & $0.00^{\mathrm{a}}$ & $0.58^{\mathrm{b}}$ & $4.36^{\prime}$ \\
\hline
\end{tabular}

Mean figures with same superscript in the column are not significantly different ( $p<0.05)$.

Key: PCV-Pack Cell Volume, Hb-Haemoglobin content, WBC-White blood cell, RBC-Reb Blood Cell, MCHC - Mean corpuscular harmoglobin concentration, MCH - Mean corpuscular haemoglobin, MCV - mean corpuscular volume, $N$-neutrophils, L- lymphocytes.

\section{DiSCUSSION}

The mean values of water quality parameter were all significantly the same $p(>0.05)$ in all the experimental containers for $C$. gariepinus fingerlings fed experimental diets for 16 weeks. These values except for nitrite $\left(0.58 \pm 0.0 \mathrm{mg} / \mathrm{l}\right.$ in diet $\mathrm{x}_{40}$ and $0.15 \pm 0.10 \mathrm{mg} / \mathrm{l}$ in $\left.\mathrm{x}_{60}\right)$ and Ammonia $(0.15 \pm$ $0.06 \mathrm{mg} / \mathrm{l}$ in $\mathrm{x}_{40}$ and $0.14 \pm 0.04$ in $\mathrm{x}_{60}$ were all within acceptable tolerant ranges recommended for fish culture (Boyd,1982, Ferraris et al., 1998). The values of the nitrite in $\mathrm{x}_{40}$ and $\mathrm{x}_{60}$ diets fell above tolerant range recommended by Boyd (1999) and were toxic to certain cold water fish and can cause reduced growth, which in this experiment was confirmed.

Haematological studies of nutritional effects and pollutants (Romao et al., 2006), brought knowledge that erythrocytes are a major and reliable indicators of various sources of stress. Moreover essential fatty acid, mineral and vitamin deficiencies or imbalance have been known to reduced red blood cell count, PCV and Hb concentrations in fish (Wedemeyer et al., 1983; Roughton and Kendrew, 1999). Haematocrit values seemed to be a more sensitive measurement of vitamin status than growth or survival and it is an easy measurement of immediate vitamin status that could be used as a predictor of future growth performance (Mulcahy, 2000; Barrow et al., 2008). All the $\mathrm{Hb}$ values for the fishes in the different dietary levels fell within the normal range value as reported by Gabriel et al. (2004) for Clarias garienpinus fish. The implication of this is that diets fed at various levels do not have 
much negative effect on the $\mathrm{Hb}$ levels of the fish and as such the oxygen carrying capacity of the blood was sufficient. Higher $\mathrm{Hb}$ level according to Joshi et al. (2002) might increase the ability of fish to enhance it activity in order to meet occasional demands. Haemoglobin is the oxygen carrying pigment in Red blood cells.

PCV or haematocrit is the percentage of total blood volume which is erythrocytes. All the values of PCV were close to the normal range and no significant differences $(\mathrm{P}>0.05)$ were seen in the dietary groups. These near normal values of the PCV were indicative of slight anaemia in the fishes which may be due to stressor such as fungal infection in the feeds (Barton and Iwama, 1991; Joshi et al., 2002). The values of the red blood cell in all the treatment groups were close to the normal ranges values for $C$. gariepinus fish. There were no significant differences $(\mathrm{P}>0.05)$ in the values of the treatment groups. The near RBC values were not unconnected with the presence of the stressor (fungal infection of feeds) which may have caused some haemodilution to occur due to impaired osmoregulation (Bitten Court, 2003). All the values recorded for RBC were indicative of slight anaemia in the fishes.

The range of values obtained for platelets in all the dietary levels fell within and some above normal range value as reported by the earlier authors (Bret, 1979; Car Michael et al., 1984; Erondu et al., 1993; Kori - Siakpere et al., 2005) An abundance of platelets in the fishes is an indication of a differential thrombocytosis which is an increase in the stimulation of platelets for good coagulation during injury (Etim et al., 1999). All the values of mean corpuscular haemaglobin concentration (MCHC), mean corpuscular haemaglobin $(\mathrm{MCH})$ and mean corpuscular volume (MCV) fell within the normal range in C. gariepinus (Gabriel and Akinrotimi, 2011), In Indian shad, Tenualosa ilisha (Jawad et al., 2004), Rainbow trout (Da et al., 2011), Yellow perch (Hien and Yen, 2005). According to Brown (1980), the red blood cell indices are used to define the size and haemaglobin content of the red blood cells. Since dietary treatments did not impact significantly on the MCHC, MCH and MCV, the fishes had similar haemaglobin contents.

The white blood cells (WBC) are cells of the immune system involved in defending the body against both infectious diseases and foreign materials. The lymphocytes are the most numerous cells comprising the leucocytes which function in the production of antibiotics and chemical substances serving as defense against infection. The primary consequences of observed changes in leucocyte count in stressed fish are suppression of the immune system and increased susceptibility to disease (Ellis, 1987). The WBC counts in all the dietary levels fell below the normal range for $C$. gariepinus fish. This decrease in the value of the WBC may be due to the reaction of the fish to the effect a stressor, which might be due to fungal growth found in corn (Moyak and Robertson, 1996), this fungal growth may have originated from a fungal organism called fumonism B1.The total WBC count production was not stimulated in any of the levels. The bone marrows are responsible for WBC production and the low values are indicative of bone marrow depression which may reduce the immunity of the fishes to infection (Wedemeyer and Wood, 1974). Ricardo et al. (1989) reported a significant reduction in WBC count of rainbow trout after exposure to a stressor (Copper toxicant). Shreck (1996) also observed a significant decrease in total WBC count of O.niloticus exposed to sublethal levels of nickel. This he attributed to the diminution in the delivery of lymphocytes production and a rapid destruction of cells which led to an increased rate of peripheral removal of lymphocytes (Ellis, 1987). Smith and Haltingh (1999) attributed such lymphonias to the stressor (toxicant). The low WBC counts were also indicative of s selective bone marrow suppression for WBC counts alone. Although there was a general depression of WBC counts, the differential percentages for the neutrophils and lymphocytes were within normal range except in $\mathrm{X}_{80}$ and $\mathrm{X}_{100}$ diets where the lymphocytes values were above the normal range and the neutrophils values in these same treatment groups were below normal range value .The increase in lymphocytes value in $X_{80}$ and $X_{100}$ dietary groups were indicative of a high level of chronic fungal infection (stressor).There was a shift in the number of neutrophils production to an increased production of lymphocytes in $\mathrm{X}_{80}$ and $\mathrm{X}_{100}$ dietary groups. Lymphocytes are known to fight against fungal infection and an increase in their number is needed to do this job (Dacie and Lewis, 1984).

\section{Conclusion}

The blood parameters in all the treatment groups were within or near the normal range values except the white blood cell. The values of the blood parameters are indicative that the leaf premix did not 
alter the functional metabolism of $C$. gariepinus fish. Sustainable small-scale catfish farming systems should require minimal external inputs and should efficiently use locally available feed resources to improve fish production and reduce feed costs. This work therefore shows that there is great potentials for using low cost supplementary feeds, including nonconventional feeds and agricultural by-products such as green leaf, to replace expensive vitamin premix in fish diet formulations.

\section{REFERENCES}

Adeogun O.A., Ajana A.M., Ayinla O.A, Yarhere M.T., \& Adeogun M.O. (2010).Application of LogitModel in Adoption Decision: A Study of Hybrid Clarias in Lagos State, Nigeria. AmericanEurasian Journal of Agriculture and Environmental Science, 4(4), 468-472.

Adewumi A.A, \& Olaleye V. F.( 2011). Catfish culture in Nigeria: Progress, Prospects and Problems. African Journal of Agricultural Research, 6(6), 1281-1285.

AIFP, (2004) Farming Nigerian Water News letter of the Aquaculture and Inland fisheries project of the National special programme for feed security in Nigeria. F.A.O Office, Abuja, Nigeria. Periodical Publications, 3(4),2-4.

Ajayi, O.T (1999). The Development of the Fisheries sub - section of Nigerian agriculture. Journal of Aquaculture Technology, 4, 23- 34.

Akinrotimi, O.A., Gabriel,U.U., Owhonda, N.K., Onunkwo, D.N., Opara, J.Y., \& Cliffe, P.T. (2007a). Formulating an environmentally friendly fish feed for sustainable aquaculture development in Nigeria. Agriculture Journal, 2(5), 606-612.

Akinrotimi, O.A., Gabriel, U.U., Anyanwu, P.E., \& Anyanwu, A.O. (2007b). Influence of sex, acclimation methods and period on haematology of Sarotherodon melanotheron. Research Journal of Biology Science, 2(3),348-352.

Akinrotimi, 0. A., Ansa, E. J., Owhonda, K. N., Onunkwo, D. N., Edun, 0. M., Anyanwu, P. E., Opara J. Y. ,\& Cliffe, P. T.(2007c). Effects of Transportation Stress on Haematological Parameters of Black Chin Tilapia, Sarotherodon melanotheron. Journal of Animal Veterinary and Advances, 6(7): 841-845.

Akinrotimi O.A; Ansa E.J; Owhonda K.N; Edun O.M; Onunkwo D.N; \& OparaY.(2007d).Variation in oxygen carrying capacity of Sarotherodon melanotheron blood in different acclimation media. Journal of Animal and Veterinary Advances, 6(8), 932-937.

Akinrotimi, O.A., Uedeme-Naa, B. and Agokei, E.O. (2010). Effects of acclimation on haematological parameters of Tilapia guineensis. Science World Journal. 5(4):1-4

Akinrotimi, O.A. Cliffe, P.T., \& Ibemere, I.F. (2011a). Integration of rural aquaculture into small scale farming in Niger Delta region of Nigeria. Global Approaches to Extension Practice, 7(1), $43-48$

Akinrotimi, O.A., Abu, O.M.G., \& Aranyo, A.A. (2011b). Transforming aquaculture from subsistence to commercial level for sustainable development in Niger Delta Region of Nigeria. Journal of Agriculture and Social Research, 11(2),22 - 33.

Akinrotimi, O.A., Gabriel, U.U., \& Deekae, S.N. (2014a). Investigation on the potential of Indian almond tree (Terminalia catappa) leaf extracts as anaesthetic agent in African catfish (Clarias gariepinus). Journal of Aquatic Sciences, 29(18), 223- 231.

Akinrotimi, O.A., Gabriel, U.U., \& Deekae, S.N. (2014b). Anaesthetic efficacy of sodium bicarbonate and its effects on the blood parameters of African catfish, Clarias gariepinus (Burchell, 1822). Journal of Aquatic Sciences, 29(13), 233 - 246.

Akinrotimi O.A., Edun, O.M., Ibama, J.E.W (2015). The roles of brackish water aquaculture in fish supply and food security in some coastal communities of Rivers state, Nigeria. International Journal of Agriculture Science and Food Technology 1(1): 012-19.

Albritton, E.C. (1992). Standard Values in Blood. Saunders Publishers, London, United Kingdom.

APHA (1998). Standard Methods for the Examination of Water and Waste $\left(16^{\text {th }} \mathrm{Ed}\right.$; Washington, American Public Health Association.

Armsby H. (1993). The principles of animal nutrition. New York, John Wiley and sons $1^{\text {st }}$ 
Bagenal, T.B., \& Tesch, F.W. (1978). Age and growth. In: T Bagenal (ed), Methods for Assessment of fish production in fresh waters, $3^{\text {rd }}$ Edn. Blackwell Scientific Publications, Deney mead, Oxford, UK.

Barrow, F.T., Gibson, T.G., Wendy, M.S., Lucas, P., \& Charlie E.S. (2008). The effect of vitamin premix inextruded planted - bias and fish mean based on growth efficiency and health of rainbow trout, Oncorhynchus mykiss. Aquaculture, 283, 148-155

Barton, B.A ., \& Iwama, G.K. (1991). Physiological changes in fish from stress in aquaculture with emphasis in the effect of cortrocosteriods. Annual Review of Fish Disease 3,26-30.

Bitten Court, N.R. (2003). Haematological and Biochemical value for nile tilapia Oreochromis niloticus culture in Semi- intensive system. Science in Biological Science Maringa 25(2),285389.

Blaxhall, P.C., \& Daisely, K.W. (1973). Routine Haematological Methods for use with fish blood. Journal of fish biology, 5, 771-781.

Boyd, C.E. (1982). Water Quality Management for Pond Fish Culture. Elsevier scientific public. company New York, USA. 318pp.

Boyd, C.E. (1999) Water Quality in Warm Water Fish Ponds. Craft Master Printers, Inc. Opelika, Alabama, USA. 359pp.

Brett, J.R. (1979). Physiological energetic. In: Fish Physiology, Vol. Vii, (Eds) W.S Hoard, D,J. Randall and J.R. Brett. Academic Press. New York.

Brown, B.A. (1980). Haematology Principles and Procedures ( $3^{\text {rd }}$ Ed). Leenz Publishers, Phinla delphia 356pp.

Car Michael, G.J., Tomasso, J.R; Simco, B.A and Davis, .K.B (1984). Characterization and alleviation of stress associated with hauling largemouth bass. Transaction of the American Fisheries Society, 113, 778-785.

Da, C.T., Hung, L.T., Berg, H., Lindberg, J.E. \& Lundh, T. (2011). Evaluation of potential feed sources, and technical and economic considerations of small scale commercial striped catfish (Pangasius hypothalamus) pond farming systems in the Mekong Delta of Vietnam. Aquaculture Research, 64, 1-13.

Dacie, J.V;. Lewis, S.N. (1984). Practical Haematology, $5^{\text {th }}$ (Ed), Churchill Livingstone, Edinburgh, $453 \mathrm{pp}$.

Ellis A. E. (1987). The leucocytes of fish: A review. Journal of Fish Biology, 11: 453-491.

Erondu, E.S., Nnubia C., \& Nwadukwe . F.O. (1993). Heamatological studies on four catfish species raised in fresh water ponds in Nigeria. Journal of Applied Ichthyology, 9 (2), 250-256.

Etim, L., Ekanem, S.B., \& Utim A. (1999). Haematological profiles of two species of catfish, Chrysicthys nigrodigitatus and Chrysicthys furcatus from the great Kwa River. Nigeria Global. Journal of Pure and Applied Sciences, 5(1), 1-8..

FAO (2004). A global information system on fishes. http/fish base org.

FAO (2012). The State of World Fisheries and Aquaculture 2012. FAO-Food and Agriculture Organization of the United Nation 00153, Rome, Italy, $230 \mathrm{pp}$.

FAO (2014). Food and Agriculture Organization of the United Nations. Inland FisheriesResources of Nigeria. Corporate Document repository. Produced by Fisheries andAquaculture Department. Accessed on 7th of March 2014 Available:http://www.fao.org/documents/en/detail/64969.

Ferraris, R.P., Catacutan, M.R., Mabelin, R.L. \& Jazul, A.P. (1986). Digestibilityin milkfish, Chanos chanos (Forsskal): effects of protein source, fish sizeand salinity. Aquaculture, 59(2), 93-105.

Gabriel, U.U., Ezeri, G.N.O., \& Opabumi O.O (2004). Influence of sex, sources health status and acclimation on the haematology of Clarias gariepinus. African Journal of Biotechnology, 3(9),433-437.

Gabriel, U.U., Akinrotimi, A.O., Anyanwu P.E., Bekible, D.O., \& Onunkwo D.N. (2007a). Locally produced fish feed: Potential for aquaculture development in Africa. Journal of Agriculture 20(10),536-540 
Gabriel, U.U., Anyanwu, P.E., \& Akinrotimi A.O. (2007b). Haematological profiles of black chinned tilapia (Sarotherodon melanotheron) from Buguma Creek, Niger Delta. Agriculture Journal, 2(3), 384-387.

Gabriel, U.U, Anyanwu, P.E and Akinrotimi A.O (2007c). Effect of fresh water challenge on the blood characteristics of Sarotherodon melanotheron. Journal of Fisheries International, 4, 112120 .

Gabriel, U.U., Akinrotimi, O.A. and Orlu, E.E. (2011a). Haematological characteristics of the bloody cockle (Anadara senilis) from Andoni Flats, Niger Delta, Nigeria. Science World Journal, 6(1), $1-4$.

Gabriel, U.U., \& Akinrotimi, O.A. (2011). Probiotics: a viable tool for sustainable aquaculture development in Nigeria. African Journal of General Agriculture science, 7(2),75 - 88

Hien, T.T.T. \& Yen, D.T. (2005). Study on nutrition requirement for 3 species catfish Pangasinodon bocouti, $P$. conchophilusand and P. hypothlamus.Ministry of Education and Training Project. College of Aquaculture andFisheires, Can Tho University, Vietnam (in Vietnamese), 60pp.

Hrubec, T.C., \& Smith S.A. (2004). Haematology and Blood Chemistry reference intervals for yellow perch (Perca flavescent) raised in recirculation systems: International Journal of Recirculation Aquaculture, 5(3), 29-42.

Jawad, L.A., Al-Mukhtar, M.A., \& Ahmed H.R. (2004). The relationship between haematocrit and some biological parameters of the Indian shad, Tenualosa ilisha. Animal Biology and Conservation, 27(2),47-52.

Joshi, P.K., Harish, D., \& Buse, M. (2002). Effect of lime on certain blood parameters in a fresh water teleost fish, Clarias batrachus. Pollution Resources, 21(1), 55-57.

Kori-Siakpere, O. J; Ake, E.G., \& Idoge, D.E. (2005). Haematological characteristics of Clarias isheriensis (syndenham). Journal of Fish Biology 27, 259-263.

Miale, J.B (1982). Laboratory Medicine Haematology. $6^{\text {th }}$ edition. The CV Moshy Pub[ishers. London. 883pp.

Mosyakin, A., \& Robertson, W.E. (1996). "New Infrageneric taxa and combinations in Amaranthus". Journal of Crop Science, 27, 236- 249.

Omitoyin, B.O. (2006). Haematological changes in the blood of Clarias gariepinus (Burchell, 1822), juveniles fed poultry litter. Living Resources Development Journal 18 (11), 1-6.

Ozigbo E, Ayaraike, C., Adegbite, O \& Kolawole, P (2014). Review of aquaculture production and management in Nigeria. American Journal of Experimental Agriculture, 4 (10) 112 - 121.

Ricardo, B., Luiz, G.E., \& Arnoldo, G.S. (1989) "Limiting amino - acids in raw and processed amaranth grain protein from biological tests" plant foods for human nutrition. Kluwer Academic Publishers Journal 39 (3): 223-234.

Romao S., Donattil Feritas, M.O., Teixeia J., \& Ksuma, J. (2006). Blood parameters analyses of some fish species. Journal Fish Biology, 10, 200-217.

Roughton, F.J.W., \& Kendrev, J.C (1999) Haemoglobin. Inter Science, 15, 234-245.

Schreck, C.B (1996). The Fish Immune System Organism and Environment. Academic Press, London, United Kingdom.

Smith, G.L. \& Haltingh, J. (1999). Haematology of some fish of marine origin. Journal of Marine Life, 21, 112-120.

Wahua, T.A.T. (1999). Applied statistics for scientific studies. Africa links books. Aba, Nigeria, $365 \mathrm{pp}$.

Wedemeyer, G.A. \& Wood, R.E. (1974). Behavioural mechanisms of metal toxicity in fishes, In: Malins D.C, Osstran Aquatic Toxicology. Molecular, Biochemical and cellular perspectives, Lewis, Bola Raton, Fl, USA., pp. $421-428$.

Wedemeyer, G.A., Could, R.W. \&. Yasutake, W.T .(1983). Some potentials and limits of the lecocrit test as fish health assessment method. Journal of Fish Biology, 23:711-716

Yisa, M \& Olufeagha, S.O. (2005). An exposition on field identification of clarlid catfishes as an important tool in fish breeding and genetics. In: proc. of the $19^{\text {th }}$ Annual conf. held at Ilorin on $29^{\text {th }}$ nov- $3^{\text {rd }}$ december 2004 (Araoye, P.A.,Ed),pp 185-192. 


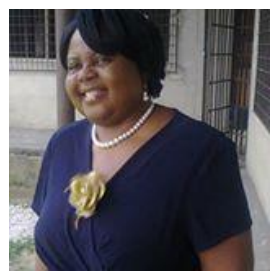

Mrs Senapuba Ariweriokuma graduated from University of Ibadan, Nigeria, with Bachelor of Science degree in Zoology (1978), obtained Master of Science (MSc) in Aquaculture, in 2008, from Rivers State University of science and Technology, Port Harcourt, Nigeria. She joined Rivers State Post Primary School Board as a class room teacher and rose to the rank of principal for many years. She retired recently as zonal director of schools in Okrika Education Zone, in Rivers State, Nigeria. She is presently a PhD student in the Department of Fisheries and Aquatic Environment, Faculty of Agriculture, Rivers State University of science and Technology, Nkpolu-Oroworukwo, Port Harcourt, Nigeria.

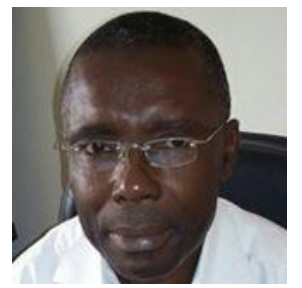

Prof. Ugwemorubong Ujagwung Gabriel holds a Bachelor of Science (B.Sc. Hons.) degree in Zoology (1988) from the University of Port Harcourt, Port Harcourt; Master of Philosophy degree in Aquaculture (1995) from the Rivers State University of Science and Technology, Port Harcourt and Doctor of Philosophy degree in Fisheries and Hydrobiology (2006) from the University of Port Harcourt, Port Harcourt, Nigeria. He started his lecturing career as an Assistant Lecturer in 1995, at the then Rivers State College of Education, now, Ignatius Ajuru University of Education, Port Harcourt. He later moved to Rivers State University of Science and Technology, Port Harcourt in 1996, where he rose to the rank of Professor in 2010. Prof Gabriel have published above a hundred articles in referred journals, he has also supervised many undergraduate and post graduate students who have successfully graduated. Prof Gabriel is an erudite scholar with many years of teaching and research experience, he has taught several specialized and general courses in Aquaculture and Fisheries at the under-and postgraduate levels including applied statistics. His research interest covered various areas of fish farming including fish nutrition, impacts of some plant extracts, agro-chemicals and hydrocarbon on the condition, mortality, behaviours, biochemistry and haematology of the clariids; effect of salinity changes on the physiology of black chin tilapia, Sarotherodon melanotheron and C. gariepinus and early life stages of the latter, the effect of culture system on the haemogram of the clariids, effect of common on farm practices on the physiology of cultured species and the use of various local plants as anaesthetics for commonly cultured species. $\mathrm{He}$ is an active member of many professional associations such as: West Indian Ocean Marine Science Association (WIOMSA); Zoological Society of Nigeria; Fisheries Society of Nigeria and Association of Aquatic Sciences of Nigeria.

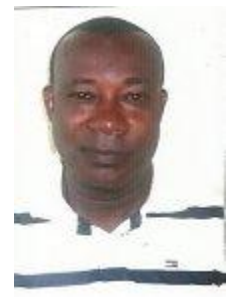

Dr Suanu Nanee Deekae obtained Bachelor of Science degree (BSc. Hons), in Zoology from University Of Port Harcourt in 1981, Master of Science (M.Sc) in Fisheries/Hydrobiology, from University of Port Harcourt in 1988, doctor of Philosophy $(\mathrm{PhD})$ from Rivers State University of Science and Technology, Port Harcourt, in 2009. He joined Nigerian Institute for Oceanography and Marine Research as research officer for many years and later moved to Federal University Of Agriculture, Umudike, in 1997. Dr Deekae later transferred his service to Department of Fisheries and Aquatic Environment, Faculty of Agriculture, Rivers State University of Science and Technology, Port Harcourt, in 2000, where he rose to the rank of Professor (associate) in the year 2013. His research focus includes fisheries management/fish biology, aquaculture, and environmental studies. He has been trained in Integrated Fish Farming at Wuxi, China and Fisheries Restocking and Stock Enhancement at Fujian Fisheries Research Institute, China. Dr Deekae have published many articles in referred journals, he has also supervised many undergraduate and post graduate students who have successfully graduated. He is an active member of many professional associations such as: Zoological Society of Nigeria; Fisheries Society of Nigeria and Association of Aquatic Sciences of Nigeria.

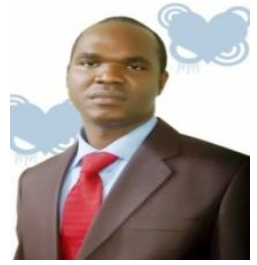

Dr. Akinrotimi Ojo Andrew graduated from Obafemi Awolowo University, IleIfe, Nigeria with Bachelor of Agriculture degree in Animal Science (1999), obtained Post graduate diploma, PGD in Fisheries; Master of Science (MSc) and Doctor of philosophy (PhD) degrees in Aquaculture, in 2007, 2009, 2014 respectively, from Rivers State University of science and Technology, Port Harcourt, Nigeria. He joined African Regional Aquaculture Centre of Nigerian 
Institute for Oceanography and Marine Research, Port Harcourt, (Affiliated to Rivers State University of Science and Technology) in 2005 as a Research officer II and rose to the rank of Principal Research officer in 2014. He is an aquaculture specialist with the scientific and technical expertise in various research activities; management of fisheries stock through mass production of fish seed and improved culture techniques of fin and shell fishes. He is also involved in health management of cultured fish, through determination of haematological and biochemical profiles. Dr Ojo has carried extensive research on toxicological evaluation and safety assessment of some marine sea food. Discovery of some botanicals that could effectively replace synthetic anaesthetics used in intensive aquaculture and stock enhancement of shell fishes (shrimps, oyster, and bloody cockle) and fin fishes (cat fish, tilapia, mullets and groupers). He has been involved in teaching and training of fisheries students (undergraduate and post graduate), and fish farmers in innovative aquacultural practices. He has published over 100 articles in both local and international referred journals, 15 papers in conference proceedings. He is presently the editor- in- chief of International Journal of Sustainable Agricultural Research Punjab, Pakistan, serves on Editorial Board of 22 International Reputable Journals across the globe. He is a member of Fisheries Society of Nigeria, and Aquatic Science Society of Nigeria. 